\title{
A AMEAÇA QUE VEM DE DENTRO: \\ O fenômeno da degradação da democracia a partir do estudo dos casos húngaro e polonês
}

\author{
Clara Giffoni Lemos ${ }^{1}$ \\ Lucas Mayon ${ }^{2}$ \\ Manuela Fernandes Bispo ${ }^{3}$
}

\section{Resumo}

A ascensão de governos chamados populistas e autoritários tem se tornado um fenômeno de amplitude mundial, que se manifesta pela chegada ao poder de governantes emblemáticos, de diferentes posições ideológicas, que clamam ser verdadeiros representantes da vontade popular. Uma vez no poder, esta narrativa se mantém e legitima diversas ações altamente criticadas. Nesse trabalho, portanto, faremos uma análise de dois países europeus que se encaixam nas características acima descritas, a Hungria e a Polônia. A partir do estudo dos cenários desses dois países, analisaremos os efeitos das políticas adotadas por esses governos sobre a o estado da democracia constitucional liberal na Europa, verificando em que medida é possível afirmar que estes países passam por crises constitucionais. Uma vez identificada a limitação deste enquadramento da tipologia de crises constitucionais para explicá-los, intentaremos enquadrá-lo como fenômeno de degradação da democracia, fenômeno caracterizado pela utilização dos aparatos democráticos para corroer a sua própria substância.

Palavras-chave: Democracia Constitucional Liberal, Populismo, Crise Constitucional, Degradação da Democracia, Leste Europeu.

\section{Abstract}

The rise of so-called populists and authoritarian governments has become a global scale phenomenon, which manifests itself through the arrival in power of governments of emblematic rulers, of all sides of the political spectrum, which claim to be the true representatives of the will of the people. Once in power, they keep these narratives, which become legitimising tools for their highly criticised actions. In this work, we will analyse two European countries which fit in the characteristics described above, Hungary and Poland. From the study of the scenario of these two countries, we will look into the effects of these governments' policies on the state of constitutional liberal democracy in Europe, verifying whether these scenarios can be framed as

\footnotetext{
${ }^{1}$ Graduanda em Relações Internacionais pelo Instituto de Relações Internacionais da Pontifícia Universidade Católica do Rio de Janeiro (IRI/PUC-Rio) e em Línguas Estrangeiras Aplicadas às Negociações Internacionais pelo Centro Federal de Educação Tecnológica Celso Suckow da Fonseca (CEFET/RJ). E-mail: giffoni.clara@gmail.com

${ }^{2}$ Graduando em Direito pela Pontifícia Universidade Católica do Rio de Janeiro (PUC-Rio) e bolsista do Programa Institucional de Bolsas de Iniciação Científica (PIBIC/CNPq) orientado pelo professor José Ribas Vieira, sob a coordenação do qual esta pesquisa se desenvolveu. E-mail: lucas.mayon@ gmail.com. ${ }^{3}$ Graduanda em Direito pela Universidade Federal Fluminense (UFF). E-mail: manuela.fernandes.bispo@gmail.com .
} 
ones of constitutional crises. Once the limitation of this framing of the constitutional crises' typology is identified, we will try to apply the concept of democratic decay, a phenomenon characterised by the use of the democratic apparatus to corrupt its own substance.

Keywords: Constitutional Liberal Democracy, Populism, Constitutional Crisis, Democratic Decay, Eastern Europe.

\section{Introdução}

Controle da mídia. Xenofobia. Captura do Judiciário. Cerceamento de liberdades. Longe de memórias distantes, essas e outras eivas de democracias pairam sobre o que se acreditavam ser países estáveis, com regimes democráticos sadios. A manifestação destas ações tem sido permitida pela significativa ascensão nos últimos anos de governos amplamente chamados de populistas (Moffit, 2016; Timbro, 2019), o que naturalmente lança dúvidas sobre o estado da democracia onde ocorrem, e, de maneira mais geral, sobre estado da democracia constitucional liberal.

Das democracias consolidadas ao redor do mundo, a multiplicação sistemática dos sintomas mencionados acima em dois países do Leste Europeu - a Hungria e a Polônia transforma-os em casos-chave para entender o momento atual para a democracia constitucional liberal. A Hungria encontra-se há quase dez anos sob um governo responsável pela deterioração constante de seu status em indicadores internacionais de democracia $^{4}$, sobretudo por conta de um discurso xenófobo e divisivo; já a Polônia, foi recentemente submetida ao governo de um novo partido, que tem chamado a atenção das autoridades europeias - e de estudiosos de ciência política - por conta dos riscos de ameaça ao princípio fundamental do Estado de Direito ${ }^{5}$.

Diante disto, o presente trabalho se dedica a analisar os governos destes dois países, visando compreender como a ascensão e a perpetuação no poder de seus líderes políticos e projetos de poder, bem como suas consequências para a saúde democrática de seus Estados, servem-nos como indicadores para caracterizar o estado atual da democracia desses países como passando por um momento crítico. Para aprofundar essa

\footnotetext{
${ }^{4}$ Vide nota de rodapé $\mathrm{n}^{\mathrm{o}} 6$.

${ }^{5} \mathrm{O}$ termo Estado de Direito se refere à forma liberal de Estado que possui, como define o professor José Afonso da Silva (1988), "como objetivo fundamental assegurar o princípio da legalidade, segundo o qual toda atividade estatal havia de submeter-se à lei”, possuindo três principais características, o de submissão do poder à lei, da divisão dos poderes e da garantia de direitos individuais.
} 
afirmação, lançaremos mão de três conceitos: o de democracia liberal constitucional, o de populismo e o de degradação da democracia (Daly, 2019a).

Assim, os estudos de caso dos contextos húngaro e polonês são úteis na medida em que levantam elementos característicos de que suas higidezes democráticas se encontram ameaçadas. A partir desta constatação, tentaremos enquadrar o cenário exposto a uma tipologia clássica da literatura norte-americana: a de crise constitucional, para então identificar em que medida o fenômeno que se delineia no Leste Europeu se restringe a um caso de crise de suas constituições ou se requer uma outra classificação. Para respondermos a esta questão principal, analisaremos mais a fundo a democracia liberal constitucional como o objeto-modelo das alterações promovidas por estes governos, isto é, a democracia liberal enquanto esquema teórico, suas definições, objetivos e seus contornos práticos. Posteriormente analisaremos o populismo enquanto fenômeno e de que maneira ele pode ser constatado nos casos em análise, bem como as limitações ao emprego de seu termo para caracterizá-los. Por fim, concluiremos enquadrando os casos descritos como parte de um movimento mais amplo, o de degradação da democracia; este como um termo globalizante, guarda-chuva, que vem sendo utilizado por Daly (2019a), e que visa descrever não apenas os últimos acontecimentos de democracias como as do Leste Europeu, mas também as de outras partes do mundo, como a turca, estadunidense, venezuelana e até mesmo brasileira. Com este percurso, pretendemos responder no que constitui o fenômeno que acomete democracias sob governos de teor autoritário ou populista.

\section{Panorama contextual}

\section{i. 0 caso da Hungria}

O primeiro-ministro Viktor Orbán e seu partido político Fidesz, no poder desde 2010, figuram como a maior representação do populismo autoritário no cenário europeu. Detentores de grande apoio popular, constroem um modelo de governo marcado pelo nacionalismo, antipluralismo e limitação de liberdades individuais em prol do interesse nacional.

Após vencer as eleições realizadas em 2018, Orbán foi eleito para o terceiro mandato consecutivo, com uma porcentagem de votos que garantiu a manutenção da maioria de assentos ao seu partido. Consequentemente, o primeiro-ministro continuou 
concentrando grandes poderes em suas mãos, visto que que a constituição húngara pode ser alterada com dois terços dos votos do parlamento. Nesse sentido, por influência do partido, já em 2013 o país possuía uma nova constituição e mais de 400 novas leis (Scheppele, 2013), em um processo de alteração legal que continuou nos anos seguintes. Tal cenário teve como agravante o controle da Corte Constitucional, a qual atuava como barreira para a efetuação das mudanças legislativas feitas pelo parlamento para alterar o sistema de eleições de juízes membros da Corte, possibilitando a nomeação de magistrados favoráveis ao executivo (Scheppele, 2013). Fica evidente, portanto, que a legislação na Hungria é constantemente alterada em prol dos interesses do governo, o que ameaça, inclusive, a independência do Poder Judiciário.

No que se refere à política econômica, constata-se um viés estatista, com a nacionalização de algumas empresas privadas, em especial as consideradas pertencentes a setores estratégicos. Somado a isso, adotam-se medidas protecionistas e taxação extra para bancos e seguradoras estrangeiras (Bugaric \& Kuhelj, 2018).

Scheppele (2019) analisa dois discursos feitos por Orbán como instrumento para aprofundar a compreensão da natureza de seu governo. No primeiro (Tóth, 2014), realizado em 2014 na Romênia, o primeiro-ministro afirma que objetiva a criação de um Estado iliberal, capaz de compatibilizar os interesses individuais e coletivos, onde os valores liberais não seriam centrais na organização do Estado, permitindo assim uma maior adaptação para a competitividade mundial. Aduz, ainda, que a democracia não é inerentemente liberal, sendo possível a compatibilização entre esta e um governo pautado em valores iliberais. No segundo (The Hungarian Government, s.d.), realizado em 2018 no mesmo local, aponta que a degradação do continente europeu se deve à substituição dos valores e instituições cristãs para a criação de uma "sociedade aberta", permissiva à entrada de imigrantes, que fragiliza o ideal familiar e a identidade nacional. Em resumo, o chefe de governo marcadamente demonstra sua aversão à primazia de valores liberais, que por vezes são considerados prejudiciais para a competitividade e identidade nacional.

Com isso, floresce uma retórica xenófoba, influenciada pela crise migratória europeia, que reiteradamente é empregada como mecanismo de exaltação nacionalista, estimulando o culto, a adesão às tradições e costumes tradicionais a fim de que se preserve a essência húngara, supostamente ameaçada pela entrada de estrangeiros no continente europeu. Este tipo de discurso contribuiu para a propagação da ideia de que existiria uma 
ameaça civilizacional islamista que, por sua vez, deu origem a um "cristianismo identitário" (Bugaric \& Kuhelj, 2018), com valores anti-Islã e pró-família.

Além disso, o controle da mídia e o uso de propagandas são meios utilizados para construção da opinião pública. Nesse ínterim, é importante analisar a lei da mídia criada em 2011. Ela estabelece um conselho responsável pelo licenciamento, licitação e nomeação de diretores de lojas públicas e com poderes de impor multas aos veículos de comunicação cuja cobertura não for considerada "politicamente equilibrada" (Sedelmeier, 2013). Consequentemente, ampliam-se as preocupações no que se refere à censura, principalmente porque os cinco membros escolhidos para os cargos são apoiadores do partido Fidesz. Uma das comprovações que legitimam esta apreensão foi, a exemplo, a suspensão da frequência do Klubradio, o principal canal de rádio independente do país (Sedelmeier, 2013), pelo órgão do governo. Verificam-se, assim, indicativos de ameaças à liberdade de imprensa, uma vez que a escolha de membros aliados aos valores do partido atua como forma de controle dos veículos de comunicação, inviabilizando a imparcialidade por meio de um confronto implícito à manifestação da oposição.

Outro exemplo do cerceamento à liberdade é observado ao analisarmos o encerramento das atividades da Central European University, em 2018 (OTT, s.d.). A universidade americana é vista como promovedora de ideais liberais que colidem com os valores cristãos antiliberais defendidos pelo governo húngaro. Seu fundador, George Soros, investidor milionário que financia organizações de valores progressistas pelo mundo, é considerado inimigo número um da nação, tendo sido estigmatizado durante toda a campanha eleitoral de Orbán, acusado de incentivar a imigração ilegal e de atuar de forma contrária ao governo. Diante disso, percebe-se uma postura nitidamente autoritária, com cerceamento à liberdade acadêmica, assim como a estigmatização do pensamento de oposição, classificando os opositores do governo como traidores da nação.

Este contexto tem sido corroborado por diversos índices que analisam o estado da democracia em diferentes países e ao longo do tempo. Um dos mais conhecidos, publicado pela organização independente Freedom House anualmente, em 2019 alterou o status da Hungria de "Livre" para "Parcialmente Livre", sob a justificativa de que o partido Fidesz tem imposto constantes ataques às instituições democráticas húngaras numa onda crescente desde 2010. Se compararmos os índices específicos a respeito da 
liberdade no geral, liberdades civis e direitos políticos, ver-se-á que do índice 1 (em uma escala de 1 a 7, em que 1 representa o cenário mais democrático) em 2009 - ou seja, um ano antes da ascensão ao poder pelo Fidesz - a Hungria passou para $3^{6}$.

Gráfico 1: Representação gráfica da evolução do índice da Freedom House na Hungria (20092019)

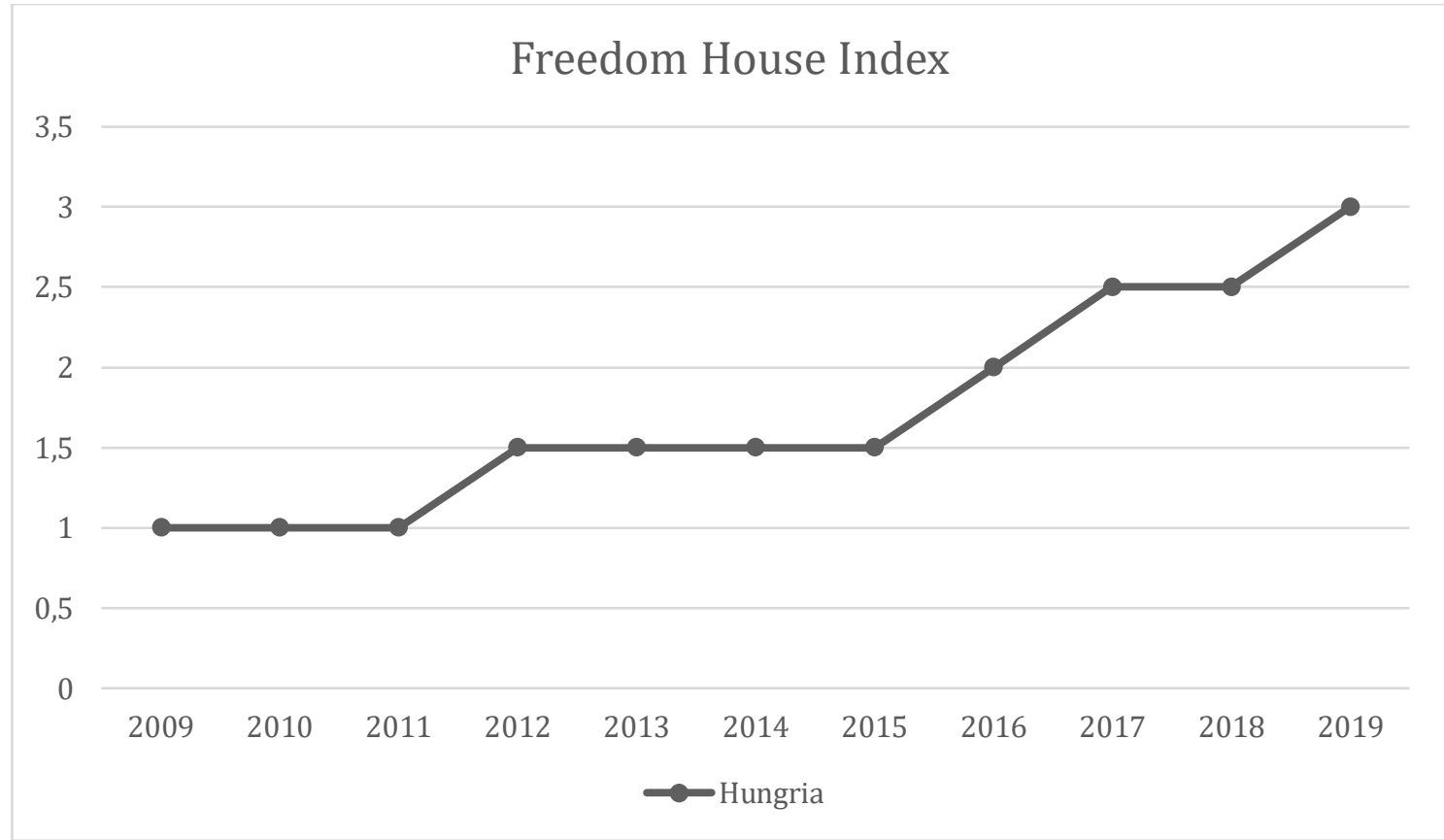

Fonte: Freedom House

\section{ii. 0 caso da Polônia}

O partido nacionalista polonês, Law and Justice (PiS), eleito em 2015, e seu líder Jaroslaw Kaczynski em conjunto com o presidente Andrzej Duda, parecem seguir pelos mesmos trilhos que a Hungria. O relatório Nations in Transit (2018), também elaborado pela Freedom House, registrou que em 2018, pelo segundo ano consecutivo, existem mais regimes autoritários consolidados do que democracias consolidadas na região do Leste Europeu. Nesse alarmante cenário, a Polônia registrou o segundo maior declínio democrático verificado em 23 anos de relatórios (Freedom House, 2018). Os motivos apontados para esse fenômeno são "a tomada do governo do sistema judicial, a politização

\footnotetext{
${ }^{6}$ Informações obtidas utilizando a ferramenta interativa da iniciativa Freedom in the World, disponível em: <https://freedomhouse.org/report/freedom-world/2019/hungary> Acessado em: 20 out. 2019.
} 
da mídia pública, campanhas de difamação contra organizações não-governamentais (ONGs) e violações do processo parlamentar ordinário".

O modelo de governo e os valores adotados se assemelham aos observados no cenário húngaro. Dentre eles, a construção de um nacionalismo católico, estimulado por uma suposta ameaça islâmica, que culmina em políticas xenofóbicas, e o antielitismo, sob a acusação de que a elite seria corrupta e agiria exclusivamente em prol de interesses individuais, ignorando as necessidades coletivas (Balkan Insight, 2019).

Nesse contexto, a adoção de políticas de bem-estar social coopera para que as classes baixas se sintam amparadas pelo governo e pertencentes ao ideal de nação. Sob essa perspectiva, as duas principais iniciativas adotadas consistem no pagamento mensal de subsídios para famílias com dois ou mais filhos com idades inferiores a 18 anos, e em diminuir a idade de aposentadoria de 67 para 60. A respeito disso, Bojan Bugaric e Alenka Kuhelj (2018) acreditam que tais medidas fazem parte de um "programa político conservador baseado em um conjunto de valores morais que supostamente servem à proteção da nação polonesa". Por fim, percebe-se que ainda que contribuam para a melhoria da qualidade de vida da população, geram uma dependência ao governo, a qual garante a manutenção do apoio político.

Mas, diferentemente da Hungria, em que o líder do governo ascendeu ao poder há quase uma década e que, portanto, há mais tempo para a instalação de um verdadeiro projeto de governo e de poder, na Polônia o Law and Justice tem pouco mais de quatro anos no comando do país. De todo modo, já sinalizou algumas medidas que preocupam estudiosos e a própria União Europeia (Comissão Europeia, 2017).

Um dos primeiros momentos de tensão com o novo governo eleito envolveu o Poder Executivo e Judiciário poloneses. O parlamento anterior havia nomeado cinco magistrados ao Tribunal Constitucional da Polônia (TK), de três vagas possíveis, o que indicava uma tentativa de preencher assentos do tribunal com magistrados aliados àqueles que os indicaram para fazer aumentar a influência de determinado projeto de poder sobre a corte. ${ }^{7}$ Esta ação tornou-se objeto de julgamento no Tribunal Constitucional, que iria analisar a constitucionalidade do ato do agora dissolvido parlamento.

\footnotetext{
${ }^{7}$ A ação em inglês recebe o nome de "court-packing".
} 
Mesmo assim, a nova legislatura - já com a expressiva presença do PiS -, em dezembro de 2015, na noite de véspera do julgamento que decidiria a constitucionalidade da indicação, procedeu à nomeação de três outros magistrados, sob o argumento de que a ação do parlamento anterior tinha sido inválida. Na mesma noite, a nomeação foi aprovada pelos representantes e os indicados foram empossados pelo primeiro-ministro.

Na manhã seguinte, o Tribunal se recusou a aceitar os novos magistrados, e proferiu o julgamento entendendo que três das cinco nomeações anteriores haviam sido feitas corretamente, e que, portanto, os três indicados anteriormente poderiam tomar posse de seus assentos na corte. Face a isso, o primeiro-ministro se recusou a empossálos, sob a justificativa de que não havia mais assentos a serem preenchidos, justamente por conta da posse que ocorrera na véspera.

Este foi apenas o episódio inicial de uma relação conflituosa que se instaurou entre os dois Poderes. De um lado, o primeiro-ministro se recusou a publicar e dar força de lei às decisões do Tribunal que seguiram, inclusive uma marcante decisão em que a corte entendeu que emendas feitas pelo governo para modificar o processo judicial seria inconstitucional. Do outro lado, o Tribunal se recusou a admitir os três juízes empossados, numa resistência liderada sobretudo por Andrzej Rzepliński, o Presidente do Tribunal.

Em dezembro do ano seguinte, com o final do mandato de Rzepliński, o Tribunal Constitucional foi tomado pelo PiS, colocando como presidente, a exemplo, uma juíza apontada pelo partido, numa clara quebra do protocolo interno de precedência da corte. Sob a sua batuta, os três juízes apontados em 2015 foram admitidos a efetivamente tomarem seus assentos na corte, três outros foram removidos e um foi forçado a abdicar.

No lado do Poder Executivo, o Ministro da Justiça e o Presidente organizaram o desmonte do Conselho Nacional do Judiciário e da Suprema Corte, um órgão responsável pela nomeação de juízes para o Judiciário polonês. A reforma mudou a regra de que juízes deveriam indicar os novos juízes para um processo inteiramente submetido a um processo do Legislativo, o que significou que assembleias legislativas por toda a Polônia ganhassem o direito de indicar os magistrados a ocuparem as cadeiras de suas regiões.

Por conta deste cenário de tensão, uma preocupação crescente tomou conta da Comissão Europeia sobre o status do Estado de Direito na Polônia, que deve zelar pela preservação desse valor fundamental constante do artigo 2 do Tratado da União Europeia (TUE). Assim, a Comissão instaurou procedimentos sob o Rule of Law Framework em 
janeiro de 2016 (TUE). O referido procedimento se insere dentro de uma estrutura apresentada pela Comissão em 2014 para tratar de "ameaças sistemáticas ao Estado de Direito em qualquer um do 28 Estados-membro da União Europeia"8 (Id., 2014, tradução nossa), e consiste numa série de medidas concretas tomadas pela Comissão em um diálogo com o país em questão para analisar o caso e propor sugestões, tanto ao país quanto às demais instâncias da União, como o Conselho Europeu.

Após dois anos de conversas, a Comissão concluiu que existe "um claro risco de uma séria quebra do Estado de Direito na Polônia"” (TUE, 2017, tradução nossa), recomendando que fosse iniciado pela primeira vez o procedimento preventivo especial previsto no Artigo 7 do Tratado da União Europeia, destinado a assegurar o valor fundamental do Estado de Direito. Dentre as razões elencadas para a ativação do mecanismo estão a impossibilidade de garantir a independência e legitimidade do Tribunal Constitucional e a constitucionalidade da legislação; o poder discricionário do Ministro de Justiça para influenciar a composição do Judiciário; e a influência do Poder Executivo na composição do judiciário e em órgãos desenhados para assegurar a independência judicial (Ibid.).

Em 2018, a Comissão Europeia denunciou a Polônia à Corte de Justiça da União Europeia por entender que ela violou o princípio da independência judicial (incluindo a inamovibilidade dos magistrados). Essa ação foi tomada quando uma nova lei polonesa diminuiu a idade de aposentadoria de 70 a 65 anos, fazendo com que 27 dos 72 magistrados da Suprema Corte corressem o risco de serem aposentados forçadamente (Id., 2018). A Corte de Justiça da União Europeia, a Comissão pediu medidas provisórias e um processo rápido, pelo risco de "danos sérios e irreparáveis" (Ibid.) à independência judicial na Polônia e, por conseguinte, ordem legal na UE.

Em 24 de junho de 2019, a Corte proferiu seu julgamento, concluindo que as medidas de diminuição da idade de aposentadoria dos juízes da Suprema Corte não eram justificadas por um objetivo legítimo, minando assim o princípio da inamovibilidade dos juízes, princípio esse essencial à sua independência (CJUE, 2019)

Este cenário de tensão segue até hoje. Recentemente a Comissão Europeia divulgou que o clima de incerteza e de ameaça ao Estado de Direito permanece,

\footnotetext{
${ }^{8}$ No original: "Systemic threats to the rule of law in any of the EU's 28 Member States".

${ }^{9}$ No original: "A clear risk of a serios breach of the rule of law in Poland".
} 
anunciando algumas das últimas medidas que fragilizavam o Estado de Direito na Polônia $(2019)^{10}$.

\section{Crise constitucional: uma categoria apropriada?}

A vida de constituições passa, inevitavelmente, por momentos de tensionamento, que são naturais ao longo da história e da vida política de um país. E na tentativa de explicar e enquadrar esses momentos, uma vasta literatura norte-americana de crise se desenvolveu nos últimos anos, cujo resultado foi uma amplitude de categorias e esquemas.

Como identificam Balkin \& Levinson (2009), o termo "crise constitucional" é um dos mais utilizados para descrever problemas com a ordem político-constitucional de um país. Como explicam os autores, o termo é normalmente empregado pelas pessoas para descrever "períodos em que instituições do governo estão claramente em conflito"11. Como eles mesmos afirmam, no entanto, "a mera existência de conflito, mesmo profundo, não pode ser a definição de crise, [porque] instituições governamentais estão sempre em conflito"12 (Balkin \& Levinson; 2009, p. 711, tradução nossa).

Com efeito, é importante restringir o termo crise constitucional para situações que de fato denotem uma crise da constituição, e não para momentos políticos acirrados em que a saúde e normatividade do texto não estão sequer em jogo. Se este cuidado não for tomado, acabar-se-á tirando do termo o seu poder descritivo, dificultando a constatação do problema com precisão quando esta for necessária.

Para lidar com este problema, os autores oferecem uma tipologia pensando em crise constitucional não em termos de discordância, mas em termos de desenho constitucional, considerando que discordâncias ocorrem na esfera da política, da arena constituída pela ordem constitucional, sem afetar a saúde da constituição. Definem, assim, as crises constitucionais como um fenômeno de falha aguda de uma constituição, um

\footnotetext{
${ }^{10}$ No original: "Polish law allows to subject ordinary court judges to disciplinary investigations, procedures and ultimately sanctions, on account of the content of their judicial decisions. Also, the new disciplinary regime does not guarantee the independence and impartiality of the Disciplinary Chamber of the Supreme Court which reviews decisions taken in disciplinary proceedings against judges. This Disciplinary Chamber is composed solely of new judges selected by the National Council for the Judiciary whose judges-members are now appointed by the Polish parliament (Sejm)" (Comissão Europeia, 2019).

${ }^{11}$ No original: "Periods when institutions of government are clearly in conflict."

${ }^{12}$ No original: "The mere existence of conflict, even profound conflict, cannot be the definition of crisis, [because] government institutions are always in conflict."
} 
verdadeiro "ponto de virada na saúde e na história de uma ordem constitucional"13 (Balkin \& Levinson; 2009, p. 714, tradução nossa), quando esta não consegue cumprir suas principais funções - a de organizar o Estado, a de limitar o poder do governante e a de conferir direitos fundamentais aos cidadãos para lhes proteger face ao poder do Estado.

São três os principais tipos de crises constitucionais esquematizados pelos autores, o de anunciada desobediência à constituição, o de desastres e o de desobediência coletiva. O primeiro deles ocorre quando os líderes políticos acreditam que as exigências da constituição requerem a sua violação, isto é, quando os líderes publicamente anunciam que não respeitarão mais a constituição por acreditaram que suas exigências são inadequadas ou excessivas, por exemplo. O segundo tipo ocorre quando a obediência e submissão às exigências de uma constituição encaminham o país à ruína ou ao desastre, e a última quando a discordância coletiva leva atores políticos a se engajarem em formas extraordinárias de protesto, que fogem do escopo da mera discordância.

O primeiro tipo, refere-se a uma desobediência anunciada à constituição pelos líderes políticos de um país para preservar a ordem social e para corresponder às necessidades daquele tempo. Aparece, então, a justificativa de que momentos extraordinários requerem medidas (e poderes constitucionais, neste caso) extraordinárias, pensamento adotado por Carl Schmitt e até mesmo por John Locke ${ }^{14}$. Independente da posição que se adote - a favor ou contra este tipo de situação - fato é que, quando ocorre, a saúde de uma constituição está em risco, a sua normatividade perde força e permite dizer que falhou em sua principal função, a de manter estável uma ordem política. Nesse tipo de crise, evidentemente, resta ameaçada uma das características fundamentais dos Estados de Direito: a supremacia da constituição.

O segundo tipo, mais raro, ocorre naqueles casos em que as cartas constitucionais, ao mesmo tempo em que instituem uma clara trajetória de desastre - seja este político, econômico ou social, não fornecem os meios para que sejam evitados. Assim, ao passo que o primeiro tipo de crise se dá quando há falta de fidelidade à constituição, neste segundo, a fidelidade excessiva conduz a ordem política-constitucional ao desastre.

\footnotetext{
${ }^{13}$ No original: "Turning point in the health and history of a constitutional order".

${ }^{14}$ Ao defender "prerogative powers," definidos como "[powers] to act according to discretion, for the public good, without the prescription of the Law, and sometimes even against it" (Locke, 1960, p. 393).
} 
São, naturalmente, muito mais difíceis de serem constatados, e os exemplos fornecidos são muito particulares à história constitucional norte-americana. De toda forma, poder-se-ia - a título exemplificativo geral - pensar numa constituição que não previsse uma ordem de sucessão para o chefe do Executivo. Nesse país fictício, caso adviesse ao Presidente, por exemplo, uma doença debilitante que lhe tirasse a capacidade de tomar as decisões necessárias e de cumprir as suas funções, muito provavelmente o respeito inquestionável às normas estabelecidas colocariam a ordem constitucional do país em risco. Ser governado por um governante incapacitado, sem nenhuma possibilidade de troca ou sucessão, facilmente conduziria o país ao desastre.

Parece-nos, contudo, que o primeiro e o segundo tipo de crise guardam uma relação ainda mais profunda. Caso um país esteja diante do cenário típico desta última crise constitucional - em que a fidelidade à constituição o encaminha ao desastre - restam apenas duas alternativas: ou continuam obedecendo a constituição (caracterizando assim a crise constitucional do segundo tipo), ou a desobedecem (o que caracterizaria uma outra crise constitucional, do primeiro tipo). E embora esta observação não tenha, por si própria, grande valor analítico, é importante pensar que o elemento de fidelidade e respeito às normas da constituição estão no centro desta tipologia, e servem como elementos-chave para a análise e classificação da saúde de uma constituição.

O último tipo de crise, por sua vez, envolve um descumprimento coletivo e generalizado das normas constitucionais por toda a sociedade, o que se manifesta na forma de conflitos internos e motins. Ocorre, em linhas gerais, quando atores políticos acreditam que seus oponentes estão tomando passos perigosos - ou mesmo ilegais - que ameaçam as fundações constitucionais da República e que arriscam trazer mudanças fundamentais e não justificadas diante do que se opõem, de maneira que extrapola o reino da ação política ordinária e envolvendo, não raro, a violência e a desordem.

Por esse motivo afirma-se que o terceiro tipo de crise é um de desobediência coletiva. Parte de uma tensão política (muitas vezes pela preocupação de que a ação do outro seja flagrantemente contrária a princípios democráticos) que se dissolve numa disputa que foge da arena instituída pela constituição, desbordando para a área da violência, manifestada em motins, revoltas e guerra civil. $\mathrm{O}$ caso mais ilustrativo trazido pelos autores é o da crise de secessão dos Estados Unidos de 1860 a 1861, que 
desencadeou a Guerra Civil americana, ela própria uma crise constitucional do terceiro tipo.

Como se constata a partir da leitura das linhas acima, longe de serem processos de longa duração e difíceis de serem apontados, crise constitucionais como definidas pelos autores Balkin \& Levinson (2009) são fenômenos com recorte bem delimitado na história constitucional de um país. Tais crises refletem uma falha sistêmica da constituição em cumprir com a sua função maior, a de criar e de sustentar um ambiente estável que permita a plena realização da vida política de um povo.

O que foge destas características já não pode ser enquadrado como crise constitucional, mas como algo diferente, que já foi tratado pelo próprio Balkin (2017) e por Tushnet (2004). De todo modo, a grande questão é se, no caso concreto, a categoria de crise constitucional é adequada para descrever o que tem acontecido nos países do Leste Europeu em questão.

A resposta parece ser negativa. Embora o crítico estado das democracias estudadas, nas quais diversas mudanças têm sido promovidas para manter líderes políticos no poder e para entrincheirar seus interesses e objetivos dentro da estrutura do Estado elas, não se encaixam em nenhuma das tipologias e cenários expostos acima das três formas de crise constitucional. Seria possível, então, afirmar que a tipologia desenhada é por demais restritiva. No entanto, recairíamos no problema de onde traçar a linha que separa a apropriada utilização do termo e o seu emprego excessivo, que lhe tira a própria utilidade.

Independente de onde se trace esta linha, o importante de se considerar é que as crises constitucionais, mais do que três categorias específicas com elementos bem definidos, são momentos restritos na história de um país em que suas constituições falham sistemicamente em promover uma esfera em que se realize a vida política daquele povo.

Este não é, parece-nos, o caso da Polônia e da Hungria. Por mais que, efetivamente, as democracias nestes países estejam passando por momentos delicados (o que pode ser interpretado como não realizando a vida política do povo), fato é que os líderes políticos foram eleitos democraticamente e com amplo apoio da população, e que promovem mudanças na ordem político-constitucional dentro dos limites da constituição anterior e em consonância com os projetos apresentados em época de eleição. 
Onde está, então, o problema? Evidentemente, ao não se tratar de crise constitucional não significa que o que está ocorrendo não caracteriza um fenômeno negativo (muitas vezes até mais perigoso do que a crise) para a história constitucional e política de um país. Muito pelo contrário, significa apenas dizer que as categorias fornecidas pela literatura de crises não conseguem responder efetivamente às complexidades dos cenários apresentados. Mais do que isso, demonstra que, ao invés de problemas de desenho constitucional, os fenômenos observados encontram-se na esfera política da discordância, o que requer a exploração de novas formas de explicar e entender os fenômenos descritos.

\section{Democracia, populismo e degradação}

Os termos democracia constitucional liberal, populismo e decadência democrática possuem uma íntima relação entre si e compreendê-la é uma importante ferramenta para que possamos explorar e entender melhor o fenômeno que aqui nos propomos a analisar. Tendo isso em vista, traçaremos um esquema teórico que nos permitirá identificar como Hungria e Polônia representam pontos críticos para a vida democrática, apresentando forte degradação.

\section{i. Democracia constitucional liberal}

A grande crítica feita aos regimes analisados é de que se constituem como ameaças à manutenção de um governo verdadeiramente democrático. Em fato, um governo verdadeiramente democrático não é meramente um que apresente eleições competitivas, como se pode pensar em um primeiro momento, mas sim aquele que disponha de liberalismo, constitucionalismo e democracia bem amarrados (Daly, 2019a), o que podemos chamar de uma democracia constitucional liberal. Nesse sentido, a simples execução de eleições periódicas não é um indício que sozinho baste para que possamos identificar governos democráticos. Por mais que comumente haja uma pluralidade de opções de voto no processo eleitoral, o que em tese garantiria eleições justas, pode ocorrer que apenas uma seja realmente uma possibilidade viável para a população, muitas vezes já saturada dos demais partidos, de modo que, de fato, só exista uma opção eleitoral e o candidato em questão ganhe por falta de demais candidaturas factíveis. 
Esse caso pode ser, não por coincidência, apontado na Hungria. Após ter saído da esfera de influência soviética em 1989, depois de um longo período de sujeição às vontades do bloco comunista, o país obteve grande sucesso em seu processo de transição, alcançando uma pluralidade de partidos políticos e a convivência harmônica entre eles durante cinco eleições, como aponta Scheppele (2013). Contudo, essa variedade foi comprometida pelo fato de os líderes de tais partidos não conseguirem preparar sucessores na geração seguinte. Segundo a autora, dos que restaram, os socialistas, que governaram entre 2002 e 2008, sofriam fortes críticas por conta da crise econômica e de escândalos de corrupção; e os neonazistas, que tinham ideias tóxicas demais mesmo para o eleitorado nacionalista. Dessa forma, Orbán demonstrou-se como a única opção factível, pois era o único com o nome publicamente reconhecido (Scheppele, 2013).

Portanto, além da verificação de eleições, para que possamos reconhecer verdadeiras democracias - democracias constitucionais liberais, como aqui chamamos -, devemos verificar se são autossustentáveis (Scheppele, 2018), isto é, se o desenvolvimento que um governo apresenta não ameaça "a possibilidade de competição política genuína e alternância no governo ${ }^{15}$ " (Daly, 2019a, p. 7). Alguns fatores podem nos ser úteis nesta identificação, como "direitos civis e políticos empregados no processo democrático, e a disponibilidade de maquinário eleitoral neutro, e a estabilidade, previsibilidade e publicidade do regime legal normalmente capturado no termo Estado de Direito $^{16}$ (Huq \& Ginsburg, 2018, p. 87, tradução nossa); somando elementos como a verificação de instituições democráticas (como a presença de um parlamento), poderes bem divididos e controlados (o judiciário sendo independente, de modo que o líder não possa alterar as leis e fechar eleições, por exemplo), mecanismos para a proteção dos direitos das minorias, mídia livre e plural e diversidade de partidos políticos (de forma que haja uma oposição legítima) (Scheppele, 2018).

A observação desses elementos se faz importante porquanto os governos que nos propomos a abordar, ainda que demonstrem eleições periódicas, representam, de alguma forma, um momento crítico para suas vidas democráticas. Isso porque, apesar de se apresentarem como democracias, também revelam características como o antipluralismo,

\footnotetext{
${ }^{15}$ No original: "The possibility of genuine political competition and alternation in government".

${ }^{16}$ No original: "Civil and political rights employed in the democratic process, and the availability of neutral electoral machinery, and the stability, predictability, and publicity of legal regime usually captured in the term "rule of law".
} 
o antiliberalismo, o conservadorismo e o nacionalismo, que, quando combinadas, podem atingir um resultado extremamente perigoso. Devemos nos atentar para o fato de que esses mesmos traços nos são antigos conhecidos, já tendo se desvelado em regimes autoritários do século XX. Naquele momento, acompanhavam políticas de severa repressão e alienação do povo, forte uso de propaganda e líderes usualmente atrelados às forças armadas, o que nos leva a pensar que, ao somarmos cada um desses fatores, teremos um protocolo de identificação do que seja o autoritarismo. Contudo, no século XXI, novos líderes autoritários aprenderam a apresentar o autoritarismo com uma nova face (Scheppele, 2013).

Para tal, vestem uma máscara democrática, copiando más práticas de boas democracias e as reunindo em algo novo, o que Scheppele (2013) chama de "Frankenstate", numa analogia ao monstro criado por Victor Frankenstein no romance de Mary Shelley. A vista disso, a verificação dos traços de uma democracia constitucional liberal supracitados passa a ser crucial, pois alguns governos, como apontam Bugaric \& Kuhelj (2018), abraçam a forma de um estado democrático, mas ao mesmo tempo erodem a sua substância, gradualmente transformando o sistema em regimes iliberais e autoritários.

Tendo isso em vista, é possível concluir que, mesmo que alguns governos se apresentem como uma "democracia", carregam em si um autoritarismo velado, possuindo um potencial grandioso para degradá-la por dentro.

Esse potencial se mostra latente nos casos húngaro e polonês. Na Hungria, por exemplo, Fidesz, o partido de Viktor Orbán, alcançou 68\% dos assentos do Parlamento em 2010, o que permitiu que qualquer medida que fosse de seu interesse pudesse ser facilmente aprovada, uma vez que a regra para a adoção de emendas constitucionais exigia dois terços dos votos. À vista disso, Orbán tinha à sua frente um caminho repleto de possibilidades, podendo instituir poderosas medidas. Uma delas, como comentado em nosso panorama, foi a adoção de uma nova Constituição e mais de 400 novas leis. Mas Orbán foi além, colocando a Corte Constitucional, que poderia se apresentar como barreira para seus planos, à mercê dos interesses do executivo, que passou a ter grande influência sobre a composição e sobre o âmbito do poder de decisão da corte, a qual teve, em janeiro de 2012, a sua jurisdição para revisar leis abstratamente removida (Scheppele, 2013). 
Com este caso podemos identificar que, apesar de Orbán e de os membros de seu partido que ocupam assentos no Parlamento terem sido eleitos dentro de um sistema democrático, os desenvolvimentos que executam dentro desse o encaminham para que não mais o seja. Evidência disso é o esforço de tais agentes para a dissolução de instituições democráticas e instrumentos de delimitação e controle dos poderes, o que fica claro ao observarmos o projeto de alienação da Corte Constitucional. Com isso em vista, faz-se perceptível um projeto de esvaziamento de elementos democráticos do atual governo húngaro, que o encaminha para um destino cada vez mais distante da democracia - essa que, perdendo seus componentes de sustentação, vai sendo deixada para trás - e mais próximo do autoritarismo.

A Polônia segue rumos bem parecidos. Depois de desrespeitar decisões do Tribunal Constitucional e da Suprema Corte que denunciavam ações do governo como inconstitucionais, esse ainda, por meio da via parlamentar, conseguiu limitar os poderes desses órgãos, aprovando nova legislação que as regessem. Ademais, como Bugaric e Kuhelj (2018, p. 603) também apontam em seu texto, o novo governo também minou o serviço civil independente e adotou nova legislação com intuito de subsumir a mídia ao controle direto do governo.

Mais uma vez é possível perceber a destituição de mecanismos de sustentação da democracia. Elementos como a preservação de instituições democráticas, a divisão e o controle de poderes e a existência de mídia livre se mostram comprometidos dentro do cenário polonês. Desse modo, novamente identificamos um afastamento de um trajeto democrático.

Podemos, à luz dos exemplos aqui tratados, constatar que o reconhecimento de governos como democráticos deve ser um processo cauteloso e que se volte à observação de fatores diversos. Dessa forma, a existência de eleições competitivas não se faz suficiente para essa análise, afinal, se isto fosse o único requisito para tal reconhecimento, os governos húngaro e polonês passariam sem grandes esforços como democráticos aos nossos olhos. Vimos aqui que é preciso ir além, o que nos leva a reconhecer a importância dos elementos constitucionais e liberais apresentados no começo deste tópico, pois é por meio destes que uma democracia consegue minar ameaças autoritárias e, de fato, ser autossustentável. 


\section{ii. Populismo}

Grande verdade é que, embora a arena democrática permita a efetivação de um governo direcionado pelos interesses do povo, cria espaços de fala que permitem, a depender das circunstâncias fáticas de cada país, o surgimento de discursos que visam capturar essa potência popular em prol de projetos de poder particulares. Tanto o governo da Hungria quanto o da Polônia não ascenderam ao poder necessariamente por representarem o melhor para suas populações, mas sim por fazê-las acreditarem em tal fato. Nesse processo, para alcançar a audiência do povo e conquistá-lo, seus líderes lançaram mão de práticas populistas, tendência que vem se mostrando notável na região do Leste Europeu, bem como no mundo como um todo ${ }^{17}$.

Como apontam Bugaric \& Kuhelj (2018) amparando-se em Mudde (2004, p. 543), populismo se trata de uma ideologia ou um movimento político que considera a sociedade como separada em dois grupos homogêneos e antagônicos, o povo puro contra a elite corrupta, e que argumenta que a política deveria ser uma expressão da vontade geral do povo. Assim, líderes populistas buscam falar em nome da população e, alcançando sucesso nesse movimento, cativam seu apoio quase incondicional. Isso permite que se tornem grandes personalidades em seus países, ganhem constantemente eleições e, portanto, consigam se perpetuar no poder.

Podemos perceber à vista disso que o populismo se apresenta como um elemento muito poderoso. Por este motivo, torna-se necessário pensar em uma distinção, como aponta Howse (2007), entre um "bom populismo" e um "mau populismo". De acordo com ele, o primeiro, assim como o segundo, é contra as elites, mas possui aspecto pluralista, não visando uma hegemonia popular, e sim um sistema político bom para todos. O segundo, por sua vez, visa a prevalência dos direitos das minorias e é favorável a medidas punitivas contra as "elites", como taxações e deportação de trabalhadores estrangeiros. O que observaremos aqui é que os casos húngaro e polonês podem ser mais bem classificados dentro do segundo tipo.

É importante comentar aqui que o termo "elites" em muitos casos não se refere necessariamente ao que podemos pensar inicialmente como as elites financeiras de um país. Em verdade, "elites" possui uma abrangência maior, de modo que abarca todos

\footnotetext{
${ }^{17}$ Como a Turquia e a Romênia, e, de certa forma, no Brasil e nos Estados Unidos da América.
} 
aqueles que possam ser mobilizados como "inimigos do povo" (Rodrik, 2018). Isso confere mais maleabilidade aos discursos populistas, tendo em vista que estes, necessitam da mobilização de uma figura inimiga para angariar apoio da população para seu lado.

À vista disso, faz-se possível afirmar que não é uma mera coincidência que o discurso de Viktor Orbán carregue tantas rivalidades. Exemplo disso é o fato que, como comentado anteriormente, o líder húngaro assume uma postura fortemente antiliberal e se posiciona duramente contra imigrantes, atrelando-os a crises econômicas e a ameaça à identidade nacional. Nesse movimento, por meio do uso da imagem de um "inimigo", ele consegue incitar mecanismos de exaltação nacionalista e, concomitantemente, reforçar sua própria imagem, como verdadeiro representante do povo. A Polônia não fica para trás, Kaczynski já tendo feito uso das mesmas incitações.

Dessa forma, o contexto pelo qual a Europa vem passando, apresentando episódios como a crise econômica de 2008 e a crise de refugiados, mostrou-se terreno fértil para que seus líderes políticos conquistassem a maioria nas urnas por meio de discursos inflamados xenófobos, iliberais e nacionalistas. Uma vez no governo, eles conquistaram poderes significativos, desmantelando uma série de instituições constitucionais liberais que permitem que uma democracia se sustente, como vimos anteriormente. Contudo, é, no mínimo, questionável se isso teria sido realmente a necessidade e o desejo da população, o que nos leva a indagar o caráter populista que tais líderes aparentam ter - tendo em vista que o populismo, por definição, se propõe a atender à vontade geral do povo.

É justamente nesta reflexão que reside o segredo de Orbán \& Kaczynski. Como Scheppele (2019, p. 329) afirma, esse "populismo" não é populismo de fato, porquanto nada dele leva em consideração o povo e as suas necessidades, desejos e preferências. Pelo contrário, o povo serve como panorama contra o qual o líder impõe seu plano para adquirir poder.

O que os líderes húngaro e polonês desempenharam, então, foi oportunismo. A dedicação que projetam no povo serve tão somente para angariar uma via rumo ao poder, este sendo o que realmente importa. Uma vez lá, a manutenção da democracia constitucional liberal se mostra desinteressante para eles que a debilitarão em prol da satisfação de suas próprias vontades e projetos. 


\section{iii. Degradação da democracia}

Uma passagem proposta por MacFarquhar (2011) nos oferece uma excelente analogia para compreendermos o fenômeno que ocorre nas democracias húngara e polonesa. $\mathrm{O}$ autor propõe uma versão atualizada do dilema do navio de Teseu:

Suponhamos que um cientista começasse a substituir as suas células, uma a uma, com aquelas de Greta Garbo aos trinta anos de idade. No início do experimento, aquele a receber as células seria claramente você, e ao final seria claramente a Garbo, mas e quanto ao meio? Parece implausível sugerir que você poderia definir uma linha entre os dois - que qualquer uma célula poderia fazer toda a diferença entre você e o não-você. [...] Não há resposta simples - é uma questão de graus ${ }^{18}$ (Daly, 2019a, p. 9 apud MacFarquhar, 2011, tradução nossa).

Nos últimos anos, a literatura sobre tal fenômeno tem se proliferado, o que é extremamente positivo, ao passo que permite uma análise mais informada e refletida sobre os eventos vividos em diversos países. De todo modo, o crescimento desenfreado de debates permitiu a criação de uma proto-Torre de Babel, com diversos autores utilizando diversas linguagens específicas, mas que, no fundo, visavam descrever o mesmo fenômeno, ou então eram partes de um grande movimento.

Democratic erosion, democratic backsliding, constitutional rot, autocratic legalism, constitutional capture e muitos outros termos específicos, como apresenta Tom Daly (2019a), são todos parte de uma constelação que resguarda, em linhas gerais, a mesma identidade. Por isso trabalharemos com o termo decadência democrática, "a degradação incremental das estruturas e da substância da democracia constitucional liberal"19 (Daly, 2019a, p. 9, tradução nossa), que, segundo o autor, serve-nos como um guarda-chuva conceitual para cobrir essa variedade de expressões.

Como Daly descreve, as ameaças à democracia que existem na atualidade raramente são óbvias até que alcancem um estágio avançado. No caso húngaro, um sistema político-democrático, que aparentemente foi bem-sucedido após uma transição

\footnotetext{
${ }^{18}$ No original: "Suppose that a scientist were to begin replacing your cells, one by one, with those of Greta Garbo at the age of thirty. At the beginning of the experiment, the recipient of the cells would clearly be you, and at the end it would clearly be Garbo, but what about in the middle? It seems implausible to suggest that you could draw a line between the two - that any single cell could make all the difference between you and not-you. (...) There is no simple answer-it is a matter of degrees."

${ }^{19}$ No original: "The incremental degradation of the structures and substance of liberal constitutional democracy"
} 
de regimes em 1989, entrou rapidamente em degradação dentro de poucos anos, de modo que na década de 2010 já passava por uma série de alterações em seus mecanismos constitucionais liberais e, assim, direcionando a democracia numa rota de colisão.

Os tópicos anteriores nos permitiram observar que, para que esta degradação democrática aconteça, não é necessário que se dê um golpe de Estado em seu sentido clássico, por exemplo. Na realidade, as alterações podem ser muito mais sutis - como aquelas do dilema apresentado acima -, sem que consigamos definir exatamente qual é a linha que divide o ponto de partida em que o Estado é claramente democrático e o ponto final, em que o seu elemento democrático se encontra tencionado. As modificações na estrutura do Estado, assim como as células no exemplo de MacFarquhar, são sutis e incrementais, e vão pouco a pouco desnaturando o seu objeto. O ciclo parece ser, assim, um em que os líderes ascendem usando a via democrática - não raro com grande popularidade e aceitação popular - para, uma vez no poder, instituírem mecanismos que minam as características que definimos acima como típicas de um Estado constitucional liberal.

Como descreve Daly, em cada caso o resultado final tem sido similar: “concentração do poder executivo, diminuição de mediação, instituições de accountability e contra majoritárias como cortes e a mídia, e reforma de regras eleitorais que dificultam tirar o governo do poder pelo voto"20 (Daly, 2019b, p. 6, tradução nossa).

Após abordarmos os casos húngaro e polonês, resta claro que esses se encaixam dentro do quadro traçado pelo autor. Os líderes dos dois países concentraram em si uma desmedida quantidade de poder e desmantelaram aquelas instituições democráticas que poderiam lhes impor limitações, o que se deixou evidente nas modificações que Orbán e Kaczynski fizeram com a Corte Constitucional e o Tribunal Constitucional e a Suprema Corte de seus países, respectivamente. Ademais, exemplos como o controle da mídia e a aprovação de novas leis e constituições reforça ainda mais de que tais contextos se enquadram como casos de degradação interna das estruturas da democracia liberal constitucional.

\footnotetext{
${ }^{20}$ No original: "A concentration of executive power, diminution of mediating, accountability and countermajoritarian institutions such as courts and the media, and a reform of electoral rules to render it more difficult to vote the government out of power."
} 


\section{Considerações finais}

O presente artigo, debruçando-se sobre o estado das democracias do Leste Europeu, identificou que a tipologia norte-americana de crises constitucionais, é insuficiente para explicar os movimentos observados nos países em tela, exigindo um novo aporte, qual seja, o de que se enquadram, na realidade, numa onda de degradação de elementos constitucionais liberais de democracias que poderiam, se assegurados, conservá-las como autossustentáveis. Para além desta constatação, dedicou-se à análise e caracterização da ordem democrático-constitucional desses países, explicitando que elementos estavam em jogo e como se coordenavam para gerar o momento crítico pelo que passam.

O fenômeno descrito exige grande atenção pois, além de representar uma ameaça aos próprios sistemas políticos dos países supracitados, também pode apontar para uma tendência que vem se consolidando ao longo dos anos no cenário global. Na Europa, essa tendência parece encontrar terreno fértil em alguns lugares, dados os contextos de crises econômica e de refugiados, que podem oportunisticamente ser mobilizados por discursos populistas para a incitação de sentimentos nacionalistas, iliberais e conservadores.

O resultado disso é o de uma instituição tão cara como a democracia encontrar-se em risco. Diante disso, medidas de enfrentamento parecem necessárias, visto que grandes casas judiciárias cerceadas, imprensa limitada, poder concentrado no executivo, direitos civis alienados e degradação do estado de direito tem encontrado vias acessíveis para se consolidarem. Embora vistam máscaras populistas, que supostamente representariam os anseios do povo, os líderes aqui tratados apresentam-se como perigos efetivos para as necessidades populares, porque minam o próprio instrumento que viabiliza o seu exercício - a via verdadeiramente democrática. Assim, é possível concluir que, ao contrário do que tais líderes costumam oportunisticamente pregar, a ameaça reside dentro das fronteiras nacionais, algo que Orbán e Kaczynski inegavelmente nos comprovam.

\section{Referências bibliográficas}

BALKAN INSIGHT. "Poland, Populism and the 'Seductive' Power of Kaczynski". Reporting Democracy. Disponível em: <https://balkaninsight.com/2019/05/24/polandpopulism-and-the-seductive-power-of-kaczynski/.> Acessado em: 05 out. 2019. 
BALKIN, Jack. Constitutional Crisis and Constitutional Rot. Faculty Scholarship Series, S158, 2017. Disponível em:

<http://digitalcommons.law.yale.edu/fss_papers/5158> Acessado em: 05 out. 2019..

; SANFORD, Levinson. Constitutional Crises. University of Pennsylvania

Law Review, fev. 2009, v. 157, n. 3.

BUGARIC, Bojan; KUHELJ, Alenka. Varieties of Populism in Europe: Is the Rule of Law in Danger? Hague Journal on the Rule of Law, v. 10, n. 1, 2018, p. 21-23.

Disponível em: <https://link.springer.com/article/10.1007/s40803-018-0075-4\#citeas> Acessado em: 05 out. 2019.

COMISSÃO EUROPEIA. European Commission presents a framework to safeguard the rule of law in the European Union. Bruxelas: 11 de março de 2014. Disponível em: <https://europa.eu/rapid/press-release_IP-14-237_en.htm> Acessado em: 05 out. 2019.

. Rule of Law: European Commission acts to defend judicial independence in Poland. Bruxelas: 20 de dezembro de 2017. Disponível em:

<https://europa.eu/rapid/press-release_IP-17-5367_en.htm> Acessado em: 05 out. 2019.

Rule of Law: European Commission launches infringement procedure to protect judges in Poland from political control. Bruxelas: 3 de abril de 2019. Disponível em: <https://europa.eu/rapid/press-release_IP-19-1957_en.htm> Acessado em: 05 out. 2019.

Rule of Law: European Commission refers Poland to the European Court of Justice to protect the independence of the Polish Supreme Court. Bruxelas: 24 de setembro de 2018. Disponível em: <https://europa.eu/rapid/press-release_IP-185830_en.htm> Acessado em: 05 out. 2019.

CJUE. The Polish legislation concerning the lowering of the retirement age of judges of the Supreme Court is contrary to EU law. Press Release No 81/19. Luxemburgo: 24 de junho de 2019. Disponível: <https://curia.europa.eu/jcms/upload/docs/application/pdf/2019-06/cp190081en.pdf> Acessado em: 05 out. 2019.

DALY, Tom Gerald. Democratic Decay: Conceptualising an Emerging Research Field. Hague Journal on the Rule of Law, v. 11, n. 1, 2019.

. Populism, Élitism and Democratic in Brazil. 14th International Human Rights Researchers' Workshop: 'Democratic Backsliding and Human Rights', Law and Ethics of Human Rights (LEHR) Journal, 2-3 jan. 2019. Disponível em: <http://dx.doi.org/10.2139/ssrn.3350098> Acessado em: 05 out. 2019.

FREEDOM HOUSE. Nations in Transit 2018: Confronting Illiberalism. Nations in Transit. Disponível em: <https://freedomhouse.org/report/nations-transit/nationstransit-2018> Acessado em: 05 out. 2019. 
HOWSE, R. Populism and Its Enemies. Workshop on Public Law and the New Populism, Jean Monnet Center, NYU Law School, 15-16 set. 2017.

HUQ, Aziz Z.; GINSBURG, Tom. How to lose a constitutional democracy. UCLA Law Review, v. 65, n. 78, 2018, p. 87.

SILVA, José Afonso da. O estado democrático de direito. Revista de Direito Administrativo, Rio de Janeiro, v. 173, p. 15-24, jul. 1988. Disponível em: $<$ http://bibliotecadigital.fgv.br/ojs/index.php/rda/article/view/45920> Acessado em: 05 out. 2019.

LOCKE, John; LASLETT, Peter (ed.). Two Treatises of Government. Cambridge, Reino Unido: Cambridge University Press, 1960.

MACFARQUHAR, L. How to be good. New Yorker, 5 set. 2011. Disponível em: <https://www.newyorker.com/magazine/2011/09/05/how-to-be-good> Acessado em: 05 out. 2019.

MATCZAK, Marcin. Poland's Constitutional Crisis: Facts and interpretations. Oxford: The Foundation for Law, Justice and Society, the Centre for Socio-Legal Studies and Wolfson College, University of Oxford, 6 jul. 2018. Disponível em: <https://www.fljs.org/content/poland's-constitutional-crisis-facts-and-interpretations> Acessado em: 05 out. 2019.

MOFFIT, Benjamin. The Global Rise of Populism: Performance, Political Style, and Representation. Califórnia: Stanford University Press, 2016, 240 p.

MUDDE, Cas. The Populist Zeitgeist. Government and Opposition, v. 29, n. 4, 2004. Disponível em: <https://doi.org/10.1111/j.1477-7053.2004.00135.x> Acessado em: 05 out. 2019.

MÜLLER, JW. The problem with Poland. The New York Review of Books, 11 fev. 2016. Disponível em: <http:// www.nybooks.com/daily/2016/02/11/kaczynski-euproblem-with-poland/> Acessado em: 05 out. 2019.

OTT, Haley. George Soros-funded university forced out of Hungary by Prime Minister Viktor Orbán. CBS News. Disponível em: <https://www.cbsnews.com/news/georgesoros-funded-central-european-university-forced-out-of-hungary-by-pm-viktor-Orbán/> Acessado em: 05 out. 2019.

RODRIK, Dani. Is Populism Necessarily Bad Economics? AEA Papers and Proceedings, vol. 108, 2018, p. 196.

SCHEPPELE, Kim Lane. Autocratic Legalism. The University of Chicago Law Review, 85:545 2018, p. 545-583.

. Not Your Father's Authoritarianism: The Creation of the 'Frankenstate'. American Political Science Association, Newsletter, inverno de 2013. Disponível em: $<$ https://www.academia.edu/2773381/Reflections_on_Democracy_in_Eastern_Europe_ 5_author_forum_> Acessado em: 05 out. 2019. 
The opportunism of populism and the defense of constitutional liberalism. German Law Journal, v. 20, n.3, 25 abr. 2019. Disponível em:

<https://doi.org/10.1017/glj.2019.25> Acessado em: 05 out. 2019.

SEDELMEIER, Ulrich. Anchoring Democracy from Above? The European Union and Democratic Backsliding in Hungary and Romania after Accession. Journal of

Common Market Studies, Special Issue 2014, 10 December 2013. Disponível em: <https://doi.org/10.1111/jcms.12082> Acessado em: 05 out. 2019.

TIMBRO. Authoritarian Populism Index. Fevereiro de 2019. Disponível em: <https://populismindex.com/wp-content/uploads/2019/02/TAP2019C.pdf> Acessado em: 05 out. 2019.

TÓTH, Csaba. Full text of Viktor Orbán's speech at Băile Tuşnad (Tusnádfürdő) of 26 July 2014. The Budapest Beacon, 29 jul 2014. Disponível em:

$<$ https://budapestbeacon.com/full-text-of-viktor-Orbáns-speech-at-baile-tusnadtusnadfurdo-of-26-july-2014/> Acessado em: 05 out. 2019.

WEBSITE OF THE HUNGARIAN GOVERNMENT. Prime Minister Viktor Orbán's Speech at the 25th Bálványos Summer Free University and Student Camp. The Prime Minister. Disponível em: <https://www.kormany.hu/en/the-prime-minister/the-primeminister-s-speeches/prime-minister-viktor-Orbán-s-speech-at-the-25th-balvanyossummer-free-university-and-student-camp> Acessado em: 05 out. 2019. 